Journal of Social Sciences 7 (4): 508-515, 2011

ISSN 1549-3652

(C) 2011 Science Publications

\title{
Quality of Life of the Rural Community: A Comparison between Three Cities
}

\author{
${ }^{1}$ Sulaiman Md Yassin, Hayrol Azril Mohamed Shaffril, \\ Bahaman Abu Samah, Md. Salleh Hassan, Mohd Shahwahid Othman, \\ Asnarulkhadi Abu Samah and Siti Aisyah Ramli \\ Laboratory of Sustainable Development and Agriculture Extension, \\ Institute for Social Science Studies, Universiti Putra Malaysia
}

\begin{abstract}
Problem statement: Pahang and Muar Rivers are two major rivers in Malaysia. In the past, these two rivers did play an important role in flourishing the economic activities of the local community and upgrading their quality of life. Does the community along these two rivers have a good quality of life? Answers for this question will bring us to the main objective of this study which is to investigate the level of quality of life of the community living along Pahang River and Muar River and to investigate any difference that might occur between the communities in Pekan, Bahau and Muar. Approach: Each of the cities is represented by 300 respondents making the overall total respondents selected for this study was 900 . This is a quantitative study and a questionnaire was used to gain the data needed. A total of seven aspects of quality of life namely home condition, physical environment, safety at the areas, social involvement and relationship, education, financial and job security and infrastructure facilities had been studied. Results: Results gained have revealed that community along Pahang River and Muar River do have a high level of quality of life. And further analysis using ANOVA have shown that there are significant differences in six of the aspects of quality of life studied. There was no significant difference identified in the aspect of education. Conclusion/Recommendation: It can be concluded that the community that live along Pahang River and Muar River have a high level in all aspects of QOL studied. It can be concluded that community in Pekan managed to record the highest mean score in three aspects of quality of life namely (1) physical environment; (2) safety at the areas and (3) social involvement and relationship. Community in Muar managed to record the highest mean score in three aspects namely (1) education; (2) financial and job security and 3) infrastructure facilities while community if Bahau was identified to have the highest mean score in the aspect of home condition.
\end{abstract}

Key words: Quality of life, rural community, rural development, pahang river and muar river

\section{INTRODUCTION}

What is quality of life: Quality of life, happiness, wellbeing and utility are often seen as one and they are frequently used interchangeably. Quality of life can be defined as an individual's perception of their position in life in the context of the culture and value systems in which they live and in relation to their goals, expectations, standards and concerns (WHOQOL Group, 1993). Quality of life quantifies the difference, or the gap, at a particular period of time, between the hopes and expectations of the individual and that individual's experiences (Calman, 1984). Quality of life is always seen as the concept of standard of living, which is based primarily on income, but in fact it is not the same. Instead, standard indicators of the quality of life include not only wealth and employment, but also the built environment, physical and mental health, education, recreation and leisure time and social belonging. If quality of life is defined as we suggest, then only the person living that life is fit to judge its quality, for only they can assess the gap between their perceived expectations and current reality (Nord, 2001).

Corresponding Author: Sulaiman Md Yassin, Laboratory of Rural Advancement and Agriculture Extension, Institute for Social Science Studies, University Putra Malaysia 
Table 1: Aspects of quality of life to be measured

Name of the researcher/organization

Athiyaman and Walzer (2008)

Malaysian Quality of Life Index (MQLI) (2004)

Nilsson et al. (2004)

The West Wicklow Rural Communities Consultation Project (2004)

Bloom et al. (2001)

Malaysia Quality of Life Index (MQLI) (1999)

Department for International Development (1999)

Felce and Perry (1995)

Barnard and Van Der Merve (1990)

Aspects of QoL emphasized

Education, health, parks and recreation, crimes free, employment opportunities

Income and distribution, working life, transport and

communication, education, housing, environment, family life, social participation, public safety and culture and leisure.

Food, strength and work, family, support and independence, spirituality and health

Transportation, Child minding provision and play facilities, access to health care, road safety, environmental services, education and training, information and advisory services, supporting local voluntary efforts

Health, education and nutrition; developing rural infrastructure and

financial institutions; promoting the involvement

of rural people in the political process; and, improving

the status of women

Income and distribution, working life, transport and

communication, health, education, housing, environment, family life, social participation and public safety

Human capital, social capital, natural capital, physical capital and financial capital

Physical well-being, material well-being, social well-being,

emotional well-being and development and activity

emotional well-being and development and activity and financial capital

Social functions, facilities, housing, standard of living,

demographic measurement, social measurement,

Aspects to be measured for quality of life: Many studies have come out with the aspects of quality of life of the rural community. Table 1 clarifies to us some of the recent studies conducted locally and internationally on the aspects to be measured for the rural community quality of life

The current situation on quality of life of the rural community in Malaysia: Malaysia is well known for its rural development. As one of the developing countries in the world, Malaysia has put focus on a number of aspects such as poverty eradication, agriculture development (Hassan et al., 2010) and ICT development (Samah et al., 2010). Besides this, the government of Malaysia has set two stages of rural development transformation and evolution. The first stage was planned from 1957-1994. Under this period two policies had been developed which were policy on Pre New Economy Policy and New Economy Policy. Under these policies, among the target of rural development set by the government were providing basic infrastructure, agriculture development based on main commodities, equity development, efforts on poverty alleviation, land and regional development and dissemination of subsidy. On the second stage of transformation (1994-2020), it is based on the New Philosophy and Policy on Rural Development which focuses on achieving the status of developed nation in 2020. Within this period, two new policies have been formulated and known as National Development Policy and National Vision Policy. Under these two policies the focuses are on balanced development, human resource development, regionalization of land development authorities, an improved quality of services for better quality of life, achieving sustainable development, poverty alleviation and lower income group, developing attractive, developed and profitable rural areas and focus of rural development on specific groups. This balanced development ideology put forward by the government is to ensure both physical development and human development goes hand-inhand The impact of these two development phases have already emerged. This is evident from on the recent statistics provided by the Ministry of Rural and Regional Development (MRRD). The impact of rural development transformation and evolution on the rural community can be clearly seen on the increase of their level of income. In 1999, it was noted that the monthly income per month per rural household was RM1,718 compared to RM2,545 in 2009. To further develop the rural areas, in the recent Tenth Malaysia Plan (10MP) a total of RM145 billion will be allocated for the physical, economic and social development in which undoubtedly the rural community is one of the main 


\section{J. Social Sci., 7 (4): 508-515, 2011}

targets of such development. The impact also can be seen on the educational development when almost half a million of the rural students were offered places at the university for pursuing their studies at bachelor level. In the period of 2006-2009, a total of 1,419.26 km of new and repaired roads have been made available in the rural area. Based on the fact that majority of the "senior people" live in the rural areas and always related to a lower QOL due to their health condition (Douki et al., 2010; Taragh and Ilali., 2010 and Shafipour et al., 2010) access to the health services has been spread widely for the rural community. This can be seen when a total of 1927 rural clinics have been established by the government. In terms of electric and water supply, under the Program of Rural Electric Supply, in 2010 a total of 14,140 houses (which before this faced electric supply problem) have been provided with this energy supply while for water supply a total of 15,383 new houses in the rural areas have been provided with tap water Ministry of Rural and Regional Development. Besides all of these, the Malaysian government has introduced 6 NKRAs (National Key Result Areas) and of course one of the main targets of such NKRAs is to enhance the rural community quality of life and the NKRAs are (1) reduction of crime rates; (2) combat corruption; (3) widening access to affordable and quality education areas; (4) raising the living standard of the poor; (5) improving the infrastructure in rural areas and (6) improving public transport in the medium term. All of these are the evidences of the emergent impacts from the decades of rural development programs, but besides these successes, does the rural community perceive that they have achieved a better quality of life?

The Pahang River and Muar River: Muar River is one of the major rivers in Malaysia. It flows through two states of Johor and Negeri Sembilan. It started at a place called Jempol in Negeri Sembilan and it flows to Malacca Straits through Kuala Muar. Muar River is well known with its richness of history and its flora and fauna. The legendary Malay warrior called Hang Tuah has been heavily related to Muar River when it is believed that Muar River was the main route used by Hang Tuah to bring "Tun Teja" (famous Malay princess) to Malacca. Along Muar River there are a number of historical places such as the famous Bukit Kepong police station, bombed bridge during World War Two which is locally known as "Jambatan Patah", two Sultan Ibrahim mosques and a place called "Kota Buruk", the place where Parameswara, the first king of Malacca transited before he went to Malacca to build his empire. Of course, Muar River is well-known with its fresh river lobster. It is a heaven for lobster anglers all around Malaysia and have a huge potential to be developed as an attraction for tourist all around the world. Muar River has a huge potential development projects such as advance transportation system (inland waterway), tourism activities such as home-stay, recreational activities such as fishing and kayaking and business activities such as shops, hotels, bed and breakfast, sand mining industries, boat making industries and stores selling local products (Yassin et al., 2010).

Pahang river covers $459 \mathrm{~km}$ long and it is the longest river in the Peninsular Malaysia. It drains an area of $29,300 \mathrm{~km}^{2}$. A total of $75 \%$ of this basin area is located in Pahang while the remaining 25\% located in Negeri Sembilan. This river system started to flow in the south east and south direction from north passing along major towns such as Kuala Lipis, Jerantut and Temerloh and finally turning eastward at Mengkarak in the central south flowing through Pekan town near the coast before discharging into the South China Sea. Major towns found in the Pahang River basin include Pekan, Marang, Temerloh, Jerantut, Kuala Lipis, Raub and Bentung. Previously, Kuala Lipis was once the administrative center for the Pahang Sultanate Empire. Raub and Bentung were once the main industrial areas for the country. Raub was famous with gold mining industry and Bentung was once the major tin producer in Malaysia. There is a lot of famous recreational and tourist destinations that can be found in the Pahang River basin. One of the attractions is the National Park; a national heritage area. The basin also houses the three most popular highland resorts, namely Cameron Highlands, Fraser's Hill and Genting Highlands where temperatures of $18-22^{\circ} \mathrm{C}$ during the day are the norm. In addition, the only two natural lakes in Peninsula Malaysia are found in the Pahang River basin; the Chini lake and Bera lake.

Pahang River and Muar River are nearly connected at a place called Jempol, in Negeri Sembilan. This was because the Serting River flows into the Bera River, a tributary of the Pahang River. Jempol River flows into Muar River. In the past, trading boats from Muar River could continue their journey until they reach Kuala Pahang in Pekan, or Kuala Lipis to continue into Terengganu, Kelantan or Perak. At Jalan Penarikan, the boats need to be pulled overland. The distance is about 300 meters and because of the pulling of boats overland, the route is named Penarikan, which is the Malay word for pulling. Figure 1 shows us the flows of Pahang River and Muar River. 


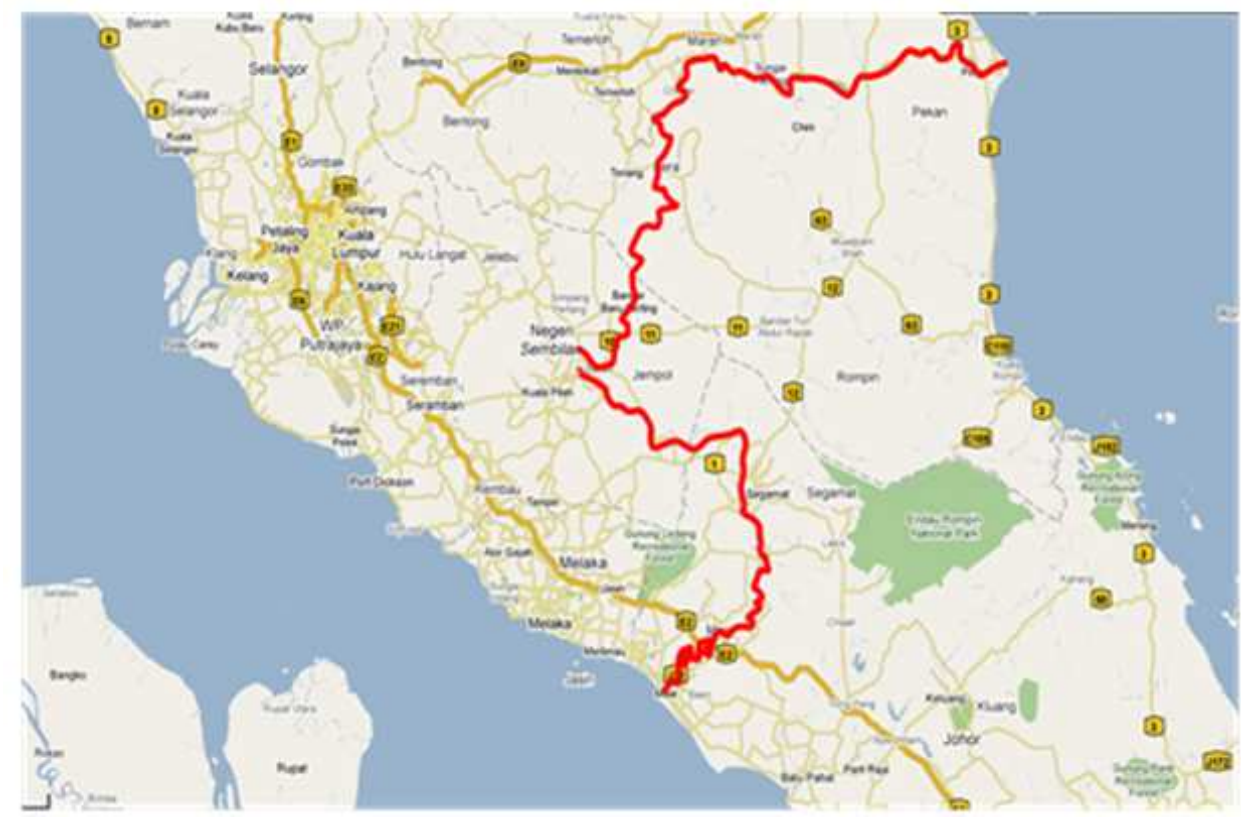

Fig. 1: Flows of Pahang River and Muar River

\section{MATERIAL AND METHODS}

This is a quantitative study and the main objective of this study is to investigate any difference that might occur in their quality of life as perceived by the inhabitants in the three cities.. Through a simple random sampling a total of 900 respondents have been selected. This number was gained from three cities along Pahang River and Muar River namely Pekan (end of Pahang River), Bahau (city where Pahang River and Muar River are nearly connected) and Muar (end of Muar River). Each of the cities was represented by 300 respondents who live near to Pahang River and Muar River. The questionnaire focused on seven aspects of quality of life namely (1) home condition; (2) physical environment; (3) safety at the areas; (4) social involvement and relationship; (5) education; (6) financial and job security and 7) infrastructure facilities. A total of 51 questions related to the quality of life have been asked to the respondents and the distributions of the questions for each of the aspect of the quality of life are described as in Table 2.

For each of the question, a five likert-like scale was used, ranging from (1) very unsatisfied; (2) unsatisfied; (3) moderately satisfied; (4) satisfied and (5) very satisfied. To interview the suitable respondents, assistance from the village leaders were gained and a total of 61 villages along Pahang River and Muar River have involved in this study. Trained enumerators facilitated the face to face interviews to gain the data needed.
Table 2: Aspects of quality of life studied

\begin{tabular}{lc}
\hline Aspects of quality of life & Number of questions \\
\hline Home condition & 11 \\
Physical environment & 7 \\
Safety at the areas & 7 \\
Social involvement and relationship & 9 \\
Education & 5 \\
Financial and job security & 7 \\
Infrastructure facilities & 5 \\
\hline
\end{tabular}

To fulfill the objectives determined, SPSS software was used where descriptive and inferential analyses were performed. Descriptive analyses such as frequency, percentage, mean and standard deviation were performed to describe the general data of the respondents studied. To determine any significant difference in the quality of life between the three cities, ANOVA was performed

\section{RESULTS}

Based on the results gained, it can be concluded that more than half of the respondents interviewed are male $(55.3 \%)$. Majority of the respondents were found to possess primary school education while only $2.1 \%$ of the respondents were found to possess Degree/Master/PhD level of education. Interestingly, more than a quarter of the respondents $(27.9 \%)$ earn between RM501-RM1000 a month. However it raises our concern when it was found that a total of $19.6 \%$ of the respondents only earn $<$ RM500 a month. 
Table 3: Background data of the respondents

\begin{tabular}{|c|c|c|c|}
\hline Level & Frequency & Percentage & Mean \\
\hline \multicolumn{4}{|l|}{ Gender } \\
\hline Male & 498 & 55.3 & \\
\hline Female & 402 & 44.7 & \\
\hline Age (years) & & & 53.50 \\
\hline$<40$ & 165 & 18.3 & \\
\hline $41-60$ & 447 & 49.7 & \\
\hline$>61$ & 288 & 22.0 & \\
\hline \multicolumn{4}{|l|}{ Level of education } \\
\hline Never been to school & 72 & 8.0 & \\
\hline Primary School & 294 & 32.7 & \\
\hline PMR/SRP/LCE & 187 & 20.8 & \\
\hline SPM/SPMV/MCE & 270 & 30.0 & \\
\hline Skills certificates & 15 & 1.7 & \\
\hline STPM/Diploma & 43 & 4.8 & \\
\hline Degree/Master/PhD & 19 & 2.1 & \\
\hline Income per month & & & 1874.74 \\
\hline$\leq \mathrm{RM} 500$ & 176 & 19.6 & \\
\hline RM501-RM1000 & 251 & 27.9 & \\
\hline RM1001-RM1500 & 155 & 17.2 & \\
\hline RM1501-RM2500 & 174 & 19.3 & \\
\hline$>\mathrm{RM} 2,501$ & 144 & 16.0 & \\
\hline Period of staying at the village (years) & & & 40.90 \\
\hline$<25$ & 250 & 27.8 & \\
\hline $26-50$ & 322 & 35.8 & \\
\hline$>51$ & 328 & 36.4 & \\
\hline Distance to the nearest city $(\mathrm{km})$ & & & 10.98 \\
\hline$\leq 5 \mathrm{~km}$ & 326 & 36.2 & \\
\hline$\overline{6}-10 \mathrm{~km}$ & 259 & 28.8 & \\
\hline$>11 \mathrm{~km}$ & 315 & 35.0 & \\
\hline Distance to nearest river & & & 0.86 \\
\hline$<250$ meter & 230 & 25.6 & \\
\hline $251-500$ meter & 237 & 26.3 & \\
\hline $501-1000$ meter & 233 & 25.9 & \\
\hline $1 \mathrm{~km}-2 \mathrm{~km}$ & 200 & 22.2 & \\
\hline Number of family members & & & 4.67 \\
\hline $1-2$ & 200 & 22.2 & \\
\hline $3-5$ & 400 & 44.4 & \\
\hline $6-7$ & 187 & 20.8 & \\
\hline$>8$ & 111 & 12.3 & \\
\hline
\end{tabular}

Majority of the respondents $(38.6 \%)$ were the senior villagers; they have stayed in the village for more than 60 years. This is followed by those who have stayed in the village for period of 26-50 years (35.8\%) and those who have stayed in the village for less than 25 years $(27.8 \%)$. It is good to know that more than one third of the respondents $(36.2 \%)$ stayed less than $5 \mathrm{~km}$ from the nearest city. It can be detected that $26.3 \%$ of the respondents stayed in the range of 250-500 meters to the river while slightly one third of the respondents $(25.6 \%)$ stayed less than 250 meters from the river. More than two fifths of the respondents (44.4\%) had 3 to 5 family members (Table 3 ).

Aspects of quality of life studied: As been mentioned earlier, there are seven quality of life aspects investigated in this study. Looking at the overall mean for each of the aspects of the quality of life studied, it can be seen that respondents studied do have a high level of satisfaction towards four aspects of quality of life namely (1) home condition; (2) safety at the areas; (3) social involvement and relationship and (4) education. The study also discovered that three aspects of quality of life namely physical environment, financial and job security and infrastructure facilities were perceived as moderately satisfied by the respondents.

For the aspect of home condition, majority respondents in Bahau (74.3\%) have a high level of satisfaction towards their home condition. The same case was recorded in Pekan (61.7\%) and Muar (71.7\%) when majority of the respondents interviewed expressed a high level of satisfaction towards their home condition.

In terms of physical environment, all of the three cities recorded a same case when majority of the 


\section{J. Social Sci., 7 (4): 508-515, 2011}

respondents in these three cities; Pekan (61.0\%), Bahau (79.7\%) and Muar (59.0\%) have a moderate level of satisfaction towards the physical environment at their areas.

It can be seen that nearly three quarters of the respondents $(72.3 \%)$ in Pekan have a high level of satisfaction towards the aspect of safety at their areas. A total of $66.7 \%$ of the respondents in Muar were found to have a high level of satisfaction towards safety at their areas. Comparatively, majority of respondents $(51.7 \%)$ interviewed in Bahau were found to have a moderate level of satisfaction towards the aspect of safety at their areas.

For the aspect of social involvement and relationship, majority of the respondents in these three cities; Pekan (74.6\%), Bahau (64.3\%) and Muar $(58.0 \%)$ were found to have a high level of satisfaction toward this aspect.

In term of education aspect, more than half respondents in Muar (59.0\%) were found to have a high level of satisfaction towards this aspect while half of the respondents $(50.0 \%)$ in Bahau also have a high level of satisfaction towards education aspects. Conversely, majority respondents $(54.0 \%)$ interviewed in Pekan have a moderate level of satisfaction towards the education aspect.

Majority of the respondents in Bahau (52.6\%) and Muar $(52.0 \%)$ were found to have a high level of satisfaction towards the aspect of financial and job security while majority respondents in Pekan (54.7\%) were found to have a moderate level of satisfaction towards this aspect.

Last but not least, for the aspect of infrastructure facilities, majority respondents in Pekan $(70.7 \%)$ were found to have a moderate level of satisfaction towards this aspect. Interestingly, majority respondents in the other two cities; Bahau (63.7\%) and Muar (58.7\%) also recorded a moderate level of satisfaction towards the aspect of infrastructure facilities (Table 4).

Differences between the three cities in term of aspects of quality of life: In the following part, we will focus on this study's main objective, which is to investigate the difference between the three cities in term of aspects of quality of life studied. Inferential analysis using ANOVA was performed to inspect any difference that might occur.

For the aspect of home condition, the study has shown that the highest mean score was recorded by respondents in Bahau $(\mathrm{M}=4.02)$ followed by respondents in Muar $(\mathrm{M}=3.90)$ and respondents in Pekan $(\mathrm{M}=3.81)$. Based on the $\mathrm{F}$ value $(3,900)=$ $11.006, \mathrm{p}<0.05$, there was significant difference with regard to home condition between the three cities studied. Further analysis using Post Hoc test revealed that there was a significant difference in this aspect between respondents in Bahau and respondents in Pekan.

For the aspect of physical environment, based on the $\mathrm{F}$ value $(3,900)=20.714, \mathrm{p}<0.05$, there was significant difference recorded. The highest mean score was recorded by the respondents in Pekan $(M=3.62)$. The second highest mean score was recorded by the respondents in Muar $(\mathrm{M}=3.53)$ while the lowest mean score was recorded by the respondents in Bahau $(\mathrm{M}=$ 3.36). Further analysis using Post Hoc test revealed that there was a significant difference in this aspect between respondents in-Pekan and respondents in Bahau.

In terms of safety at the areas, based on the the $\mathrm{F}$ value $(3,900)=17.749, \mathrm{p}<0.05$, there was significant difference recorded between the three cities studied. Further analysis done have detected that there was a significant difference in the aspect of safety at the areas between Pekan and Bahau. This is not surprising as Pekan emerged with the highest mean score $(\mathrm{M}=3.93)$ and Bahau showed the lowest mean score $(M=3.62)$.

Another aspect studied is the social involvement and relationship. The highest mean score was recorded by respondents in Pekan $(\mathrm{M}=4.06)$, followed by respondents in Bahau $(M=3.93)$ and the lowest mean score was recorded by respondents in Muar $(\mathrm{M}=3.83)$. Based on the analysis, it revealed that $\mathrm{F}$ value $(3,900)$ $=14.117, \mathrm{p}<0.05$, there was significant difference recorded in the aspect of social involvement and relationship between the three cities studied.

Education is one of most emphasized aspects for developing community quality of life and do the communities in these three cities have a high level of satisfaction toward the education aspect? Based on the results presented in Table 5, the study discovered-that all of the three cities recorded a good mean score; Pekan $(\mathrm{M}=3.72)$, Bahau $(\mathrm{M}=3.72)$ and Muar $(\mathrm{M}=$ 3.77). Based on the analysis carried out, it revealed that $\mathrm{F}$ value $(3,900)=0.736, \mathrm{p}>0.05$, thus there was no significant difference recorded; a good sign that communities in these three cities have admitted the educational development at their areas.

For the aspect of financial and job security, the highest mean score was recorded by respondents in Muar $(M=3.58)$, followed by respondents in Bahau ( $M$ $=3.49)$ and respondents in Pekan $(\mathrm{M}=3.33)$. Based on the analysis run, it revealed that $F$ value $(3,900)=$ $6.166, \mathrm{p}>0.05$, indicates that there was significant difference between the three cities studied. Further analysis through Post Hoc test has detected that there was significant difference between respondents in Muar and respondents in Pekan. 
J. Social Sci., 7 (4): 508-515, 2011

Table 4: Aspects of quality of fife studied

\begin{tabular}{|c|c|c|c|c|}
\hline Quality of life aspects & Pekan & Bahau & Muar & Overall mean score level \\
\hline Home condition & $\mathrm{M}=3.81$ & $\mathrm{M}=4.02$ & $\mathrm{M}=3.90$ & $\mathrm{M}=3.91$ \\
\hline Low (1-2.33) & 0 & 0.7 & 0.7 & \\
\hline Moderate (2.33-3.66) & 38.3 & 25.0 & 27.7 & \\
\hline High $(3.67-5.00)$ & 61.7 & 74.3 & 71.6 & \\
\hline Physical environment & $M=3.62$ & $\mathrm{M}=3.36$ & $\mathrm{M}=3.53$ & $M=3.50$ \\
\hline Low $(1-2.33)$ & 0 & 0.3 & 1.7 & \\
\hline Moderate (2.33-3.66) & 61.0 & 79.7 & 59.0 & \\
\hline High $(3.67-5.00)$ & 39.0 & 20.0 & 39.3 & \\
\hline Safety at the areas & $\mathrm{M}=3.93$ & $\mathrm{M}=3.62$ & $\mathrm{M}=3.81$ & $\mathrm{M}=3.79$ \\
\hline Low $(1-2.33)$ & 0.3 & 3.0 & 1.7 & \\
\hline Moderate (2.33-3.66) & 27.3 & 51.7 & 31.7 & \\
\hline High $(3.67-5.00)$ & 72.3 & 45.3 & 66.7 & \\
\hline Social involvement and relationship & $M=4.06$ & $M=3.93$ & $\mathrm{M}=3.81$ & $M=3.94$ \\
\hline Low $(1-2.33)$ & 0.7 & 0.3 & 1.0 & \\
\hline Moderate (2.33-3.66) & 24.7 & 35.3 & 41.0 & \\
\hline High (3.67-5.00) & 74.6 & 64.4 & 58.0 & \\
\hline Education & $\mathrm{M}=3.72$ & $M=3.72$ & $\mathrm{M}=3.77$ & $\mathrm{M}=3.73$ \\
\hline Low (1-2.33) & 0 & 0.3 & 0.7 & \\
\hline Moderate (2.33-3.66) & 54.0 & 49.7 & 40.0 & \\
\hline High $(3.67-5.00)$ & 46.0 & 50.0 & 59.3 & \\
\hline Financial and job security & $\mathrm{M}=3.33$ & $M=3.49$ & $\mathrm{M}=3.58$ & $\mathrm{M}=3.48$ \\
\hline Low $(1-2.33)$ & 8.3 & 15.7 & 8.7 & \\
\hline Moderate (2.33-3.66) & 54.7 & 31.7 & 39.3 & \\
\hline High $(3.67-5.00)$ & 37.0 & 52.6 & 52.0 & \\
\hline Infrastructure facilities & $\mathrm{M}=3.10$ & $M=2.99$ & $\mathrm{M}=3.28$ & $\mathrm{M}=3.12$ \\
\hline Low $(1-2.33)$ & 11.3 & 19.3 & 11.7 & \\
\hline Moderate (2.33-3.66) & 70.7 & 63.7 & 58.7 & \\
\hline High $(3.67-5.00)$ & 18.0 & 17.0 & 29.6 & \\
\hline
\end{tabular}

Table 5: Differences in the aspects of quality of life studied between the three cities

\begin{tabular}{|c|c|c|c|c|c|}
\hline Variables & $\mathrm{n}$ & Mean & SD & $\mathrm{F}$ & $\mathrm{p}$ \\
\hline Home condition & & & & 11.006 & 0.0001 \\
\hline Pekan & 300 & 3.810 & 0.5010 & & \\
\hline Bahau & 300 & 4.020 & 0.5670 & & \\
\hline Muar & 300 & 3.900 & 0.5430 & & \\
\hline Physical environment & & & & 20.714 & 0.0001 \\
\hline Pekan & 300 & 3.620 & 0.4400 & & \\
\hline Bahau & 300 & 3.360 & 0.4500 & & \\
\hline Muar & 300 & 3.530 & 0.5620 & & \\
\hline Safety at the areas & & & & 17.749 & 0.0001 \\
\hline Pekan & 300 & 3.930 & 0.6160 & & \\
\hline Bahau & 300 & 3.620 & 0.6810 & & \\
\hline Muar & 300 & 3.810 & 0.6220 & & \\
\hline Social involvement and relationship & & 14.117 & 0.0001 & & \\
\hline Pekan & 300 & 4.060 & 0.5220 & & \\
\hline Bahau & 300 & 3.930 & 0.5530 & & \\
\hline Muar & 300 & 3.830 & 0.5810 & & \\
\hline Education & & & & 0.736 & 0.4790 \\
\hline Pekan & 300 & 3.720 & 0.5030 & & \\
\hline Bahau & 300 & 3.720 & 0.6590 & & \\
\hline Muar & 300 & 3.770 & 0.5770 & & \\
\hline Financial and job security & & & & 6.166 & 0.0020 \\
\hline Pekan & 300 & 3.330 & 0.7280 & & \\
\hline Bahau & 300 & 3.490 & 1.0970 & & \\
\hline Muar & 300 & 3.580 & 0.8430 & & \\
\hline Infratructure facilities & & & & 12.349 & 0.0001 \\
\hline Pekan & 300 & 3.100 & 0.6250 & & \\
\hline Bahau & 300 & 2.990 & 0.7440 & & \\
\hline Muar & 300 & 3.280 & 0.753 & & \\
\hline
\end{tabular}

For the last aspect, which is the infrastructure facilities, based on the $F$ value $(3,900)=12.349, p<.005$, there was a significant difference detected between the respondents in the three cities studies. Post Hoc test has 


\section{J. Social Sci., 7 (4): 508-515, 2011}

revealed that there was significant difference recorded between respondents in Muar and respondents in Bahau and this is not surprising as the highest mean score was recorded by respondents in Muar $(\mathrm{M}=3.28)$ while the lowest mean score was recorded by respondents in Bahau ( $\mathrm{M}=2.99)$.

\section{DISCUSSION}

What does the study data mean when they are transposed with the outlay of the two rivers? This study is the first of its kind that is attempting to relate the community quality of life with what both history and the two rivers have endowed for the three cities studied.

Firstly, it is quite clear that Bahau, being in the hinterland in regards to both rivers is quite "distant" from the river mouths where Pekan and Muar are situated. This bears greatly onto the level of sophistication or intensity of development that the three cities have gone through. Historically too, Penarikan was just a transit point when boats used to ply up and down the Pahang and Muar rivers. This fact is reflected in that Bahau's scores on three of the measures ranked last as compared to Pekan's two and Muar's one. This fact is further augmented by the fact that Bahau lagged behind in physical environment, infra-structure facilities and safety in the area, they being the thrusts of development in the last three decades.

Secondly, it is very interesting to note that Pekan ranked first on three related aspects, they being physical environment, safety in the area and social involvement and relationship. It does reflect on the upsurge of development activities now on-going in the East Coast of Peninsular Malaysia and the positive nature of the social capital there, especially if this is compared to those same aspects for Bahau. Pekan is also the centre of the East Coast Economic Region (ECER) regional development programmed.

Thirdly, this study further revealed that the sense of financial and job security was lowest in Bahau and highest in Muar, a thriving city where the mighty Muar river still offered additional opportunities for the surrounding community.

Fourthly, Bahau ranked highest on the home condition score. This is a very interesting finding because despite being in the hinterland, the Bahau community had found respite in their homes, which provided them a greater sense of security, albeit most of the homes were on inherited land bound by the customary matrilineal system found in Negri Sembilan.
Last but not least, this study revealed that the communities that live along the two rivers are an important component of the population that can become the focus of home-grown and communitydriven development. Overall, the quality of life scores were good to moderate and are likely to be further improved with the implementation of the newly launched Economic Transformation Programme (ETP) of the government, with enhancing the agriculture sector and the improvement of rural incomes being two of the National Key Economic Areas (NKEA). It is also heartening that education was one of the aspects which was well regarded by the respondents in all three cities studied.

\section{CONCLUSION}

QOL is indeed one of the contributors for rural community development; it is also an outcome that is often focused upon. Based on the results gained, it can be concluded that community that live along Pahang River and Muar River have a high level in all aspects of QOL studied. It can be concluded that community in Pekan managed to record the highest mean score in three aspects of quality of life namely (1) physical environment; (2) safety at the areas and( 3) social involvement and relationship. Community in Muar managed to record the highest mean score in three aspects namely (1) education; (2) financial and job security and (3) infrastructure facilities while community if Bahau was identified to have the highest mean score in the aspect of home condition. Table 6 below is the ranking of the cities in each aspect of QOL studied. It also can be identified that there was a significant difference in all aspects of quality of life studied (except aspect of education), between the three cities.

It is good to know that there was no significant difference in the aspect of education between the three cities, thus indicating to us a strong probability that communities in these three cities are equally satisfied with the educational development that had taken place in their areas.

\begin{tabular}{|c|c|c|c|}
\hline Aspects of QOL & Ranking 1 & Ranking 2 & Ranking 3 \\
\hline Home condition & Bahau & Muar & Pekan \\
\hline Physical environment & Pekan & Muar & Bahau \\
\hline Safety at the areas & Pekan & Muar & Bahau \\
\hline $\begin{array}{l}\text { Social involvement and } \\
\text { relationship }\end{array}$ & Pekan & Bahau & Muar \\
\hline Education & Muar & Pekan & Bahau \\
\hline Financial and job security & Muar & Bahau & Pekan \\
\hline Infrastructure facilities & Muar & Pekan & Bahau \\
\hline
\end{tabular}




\section{J. Social Sci., 7 (4): 508-515, 2011}

\section{REFERENCES}

Athiyaman, A. and N. Walzer, 2008. Strategies to enhance and maintain quality of life: The case of non-metropolitan Illinois. J. Rural Community Develop., 3: 41-59.

Barnard, P and J.N.K. Van Der Merve, 1991. Measuring the quality of life in rural community development. Soc. Indic. Res., 24: 57-70.

Bloom, D.E., P.H. Craig and P.N. Malaney, 2001. The Quality of Life in Rural Asia. 1st Edn., Oxford University Press, Oxford, ISBN: 0195924533 , pp: 310.

Calman, K.C., 1984. Quality of life in cancer patientan hypothesis. J. Med. Ethic., 10: 124-127. DOI: 10.1136/jme.10.3.124

DFID, 1999. Sustainable Livelihood Guidance Sheet. Department for International Development.

Douki, Z.E., N. Vaezzadeh, M. Zakizad, S. Shahmohammadi, R. Sadeghi and R.A. Mohammadpour, 2010. Changes in functional status and functional capacity following coronary artery bypass surgery. Pak. J. Biol. Sci., 13: 330-334.

Felce, D. and J. Perry, 1995. Quality of life: Its definition and measurement. Res. Develop. Disabilities, 16: 51-74. DOI: 10.1016/08914222(94)00028-8

Hassan, M.S., H.A.M. Shaffril, B.A. Samah, M.S.S. Ali and N.S. Ramli., 2010. Agriculture communication in malaysia: the current situation. Am. J. Agric. Biol. Sci., 5: 389-396. DOI: 10.3844.ajab.ssp.2010.389-396

Hayrol Azril, M.S., U. Jegak, M. Asiah, A.N. Azman and A.S. Bahaman et al., 2010. Can quality of work life affect work performance among government agriculture extension officers, a case from Malaysia. J. Soc. Sci., 6: 64-73.
Nilsson, J., M.G. Paker and Z.N. Kabir, 2004. Assessing Health-Related Quality of Life among Older People in Rural Bangladesh. J. Trans. Nurs., 15: 298-307. DOI: 10.1177/1043659604268968

Nord, E., 2001. The desirability of a condition versus the well-being and worth of a person. J. Health Econo. 10: 579-581. DOI: 10.1002/hec.647

Samah, B.A., H.A.M. Shaffril, M.A. Hassan and J.L. D?Silva., 2011. Can technology acceptance model be applied on the rural setting: The case of Village Development and Security Committee in Malaysia. J. Soc. Sci., 7: 113-119. DOI: 10.3844/jssp.2011.113.119

Shafipour, V., H. Jafari, L. Shafipour and E. Nasiri, 2010. Assessment of the relationship between quality of life and stress in the hemodialysis patients in 2008. Pak. J. Biol. Sci., 13: 375-379.

Taragh, Z. and E. Ilali, 2010. Quality of life among multiple sclerosis patients. J. Applied Sci., 10: 1485-1488.

The West Wicklow Rural Community Consultation Project, 2004. Addressing quality of life issues in rural communities. POBL Community Development Agency.

WHOQOL Group (1993). Study protocol for the World Health Organization project to develop a quality of life assessment instrument (WHOQOL). J. Qual. Life Res., 2: 153-159. DOI: 10.1007/BF00435734

Yassin, S.M., H.A.M. Shaffril, M.S. Hassan, M.S. Othman, A.A. Samah dan A.A. Bahaman., 2010. Prospects of Waterway Development as a Catalyst to Improve Regional and Community SocioEconomy Level., Am. J. Econ. Bus. Admin., 2: 240-246. DOI: 10.3844/ajebasp.2010.240.246 